\title{
VERBAL COMMUNICATIONS ANALYSIS USED BY VILLA BESAR STAFF IN HANDLING THE CUSTOMERS
}

\author{
Ni Komang Purwaningsih', Si Putu Agung Ayu Petiwi Dewi ${ }^{2}$ \\ Program Studi S1 Keperawatan \\ STIKES Bina Usada Bali \\ purwa_englishlecturer@yahoo.co.id'1 , gungayoe@gmail.com²
}

\begin{abstract}
Abstrak
Industri pariwisata adalah salah satu komponen terbesar dari ekonomi global. Pesatnya pertumbuhan industri pariwisata di Bali menyebabkan permintaan yang luas dari keterampilan berbahasa Inggris di semua aspek. Penelitian ini bertujuan untuk mengidentifikasi analisis komunikasi verbal yang digunakan oleh staf Villa Besar dalam menangani pelanggan. Penelitian ini menggunakan kuesioner tertutup dan terbuka. Penelitian ini menggunakan metode observasi atau observasi partisipan. Observasi partisipan dilakukan untuk mendengarkan dan mengamati percakapan antara staf Vila Besar dan pelanggan asing. Sampel penelitian ini adalah seluruh staf Villa Besar di Jalan Bumbak. Sampel diambil dengan menggunakan total sampling di mana seluruh populasi yang memiliki karakteristik tertentu digunakan sebagai sampel. Berdasarkan hasil penelitian dan analisis kuesioner yang dibagikan kepada seluruh staf Villa Besar, dapat disimpulkan bahwa sebagian besar responden adalah perempuan dengan usia antara 31-35 tahun, tetapi mereka berasal dari tingkat pendidikan yang lebih rendah dan memiliki pengalaman bekerja 6-10 tahun. Mereka menganggap bahwa bahasa Inggris sangat diperlukan dalam pekerjaan mereka. Beberapa masalah terjadi dalam komunikasi verbal mulai dari aktivitas berbicara yang paling sulit hingga termudah. Beberapa faktor memengaruhi kinerja komunikasi verbal mereka di antaranya kondisi kerja, motivasi, percaya diri, perasaan cemas dan malu. Penelitian ini diharapkan menjadi pertimbangan bagi manajemen vila dalam menyediakan beberapa kursus bahasa Inggris bagi para staf untuk meningkatkan kemampuan mereka.
\end{abstract}

Kata kunci: komunikasi verbal, pelanggan, efek

\begin{abstract}
The tourism industry is one of the largest components of the global economy. The rapid growth of tourism industry in Bali causes broad demand of English speaking skills in all aspect. This study aimed at identifying verbal communications analysis used by Villa Besar staff in handling the customers. This study used close and open-ended questionnaire. This study used observation method or participant observation. Participant observation was conducted in order to listen and observe the conversation between villa Besar staff and foreigner customers. The sample of this study was all of the villa Besar Staff at Jl. Bumbak. The sample was taken by using total sampling where the entire population who had a particular set of characteristics had been examined. Based on the research finding and analysis of questionnaire distributed to all of Villa Besar staffs, it could be concluded that most of the respondents were female with the age mostly between 31-35 years old, but they came from lower education level with frequently had working experience 6-10 years. All of them highly considered that English is necessary in their job. Some problems occurred in verbal communication starting from the most problematic activity until the easiest skills in speaking. Some factors affect their verbal communication performance including performance condition, motivation, self-confident, felt anxiety and ashamed. This study could be useful for the villa management in providing some English courses for the staffs in order to improve their ability.
\end{abstract}

Keywords: verbal communication, customers, effect 


\section{INTRODUCTION}

In sector of services, tourism industry plays an important role in meeting human needs. The tourism industry is one of the largest components of the global economy. The rapid growth of tourism industry in Bali causes broad demand of English speaking skills in all aspect. Language proficiency is necessary for staff in the tourism industry especially in villa. As English is now both popular and important for tourism, staffs' demand for English has increased accordingly. Xianmei Sun, (2012), commented that English is the language of the world. With the fast progressing of modernization, international communication happens more frequently. Kostic Bobanovic, M., (2011), stated that communication is an important element of hospitality industry. Verbal communication is the production skill that is included in two main categories: accuracy and fluency. Accuracy consists of using vocabulary, grammar and pronunciation through some activities, fluency take into account "the ability to keep going when speaking spontaneously"

However, lack of English skills and difficulty in communicating with foreign customers affect the service and customers' satisfaction. As Brown (2000) states successful oral communication in the target language with other speakers serves as a display of successful language acquisition. This statement brings forth the significance of developing speaking skill. In terms of problems for communication skills, some difficulties in English communication, as follows: interference from mother tongue, lack of opportunity to use English in their daily life, being too shy to speak with foreigners and lack of responsibility for their own practice and learning.

The current study addressed three issues about the problem encountered by Villa Besar staff in communicating with foreign customers, factors that affect their verbal communication performance and organizational support for English in improvement. The results of this study are expected to add insight or knowledge to the staff in Villa Besar on ways to effectively communicate within provide services to be easily understood by the foreign customers in order to make service will be better and understand the message conveyed by foreign customers to avoid happening misconceptions in communicating that have a negative impact on services, in order to maintain customer perception that is positive towards the existence of this villa. Therefore it will be beneficial for villa management to analyze these findings and organize specific plans to improve the staff English language skills in the future. The output of this research is scientific publication in local journal with ISSN and module enrichment. Literature review contains some parts such as: empirical review which was done by reviewing previous studies to understand how they bring the matters into analysis. The next one is theoretical review is several concepts related with verbal communication, characteristics of speaking skill, and factors affecting speaking skill. There are some relevant previous studies which had been done. These studies gave some contributions to this study, they are: Tanveer (2007) examined the factors caused anxiety for learners in learning speaking ability and the impact of anxiety on target language communication. The obtained results indicated that learners' feeling of stress and anxiety stop their language learning and performance abilities. The researcher emphasized that the high anxiety lowers the learners' speaking performance. Eissa, Misbah, and Najat (1988) performed a study towards the difficulties of using English as a means of instruction and communication. The results of this study displayed that 
learners had many difficulties in using English language as a means of instruction. A lot of participants stated that their learners have low English proficiency. The results also indicated that a lot of learners faced serious difficulties in understanding the lectures' content without translating or applying $L 1$ to deliver the content of the lectures.

Theoretical Review : (1) Verbal Communication, Almost every job requires workers to use verbal communication skills, especially for those who work in tourism sectors. Therefore, this skill becomes highly ranked to determine the people who are proper engaged in this sector. The stronger someone's communication skills, the better his/her chances of getting hired regardless of the job for which they are applying. Verbal communication including both how someone deliver messages and how someone receive them. Verbal communication in a tourism sector takes place between many different individuals and groups such as co-workers, bosses and subordinates, employees and also guests.

Verbal communication makes the process of conveying thoughts easier and faster, and it remains the most successful form of communication. Effective verbal communication occurs during conversations when the speaker acknowledges the sensitivity of the subject, time constraints and types of questions the receiver might ask. If the conversation occurs face to face, successful communicators use active listening skills such as repeating back what the other person has said. They also resist the temptation to interrupt and allow the other person to speak up as well to convey their thoughts. If the conversation occurs by telephone, the participants need to pay even more attention. (2) Characteristics of Speaking Skill, Efrizal (2012) expressed that speaking is of great significance for the people interaction where they speak everywhere and every day. The first characteristic of speaking performance is fluency. According to Hughes (2002), fluency is the learners' ability to speak in understandable way in order not to break down communication because listeners may lose their interest. Hedge (2000) expressed that fluency is the ability to answer coherently by connecting the words and phrases, pronouncing the sounds clearly, and using stress and intonation. The second characteristic of speaking performance is accuracy. People should be fluent in learning a foreign language. People should pay enough attention to the exactness and the completeness of language form when speaking such as focusing on grammatical structures, vocabulary, and pronunciation (Mazouzi, 2013).

According to Harmer (2001), elements that are necessary for spoken production like connected speech (a speaker needs to know not only how to produce the individual phonemes of English, but also how one word is usually followed by one or two words. They need to know the word that is used in a certain order together), expressive devices (changing pitch and stress of specific parts of pronunciation, varying volume and speed, presenting nonverbal to give feeling to words, are the devices that contributes to the ability to convey meaning), lexis and grammar (the use of a number of common lexical phrases makes for spontaneous speech), and also negotiation language (used to clarify in effective speaking).

Factors Affecting Speaking Skill, Someone' speaking performance are influenced by factors like performance conditions, affective factors, listening skill, and feedback during speaking tasks 
(Tuan \& Mai, 2015). The first factor is pertinent to performance conditions. The people carry out a speaking activity under different conditions. Performance conditions impact speaking performance and these conditions involve time pressure, planning, the quality of performance, and the amount of support (Nation \& Newton, 2009).

The second factor is related to affective ones. A lot of affective variables have been connected to second language acquisition and motivation, self-confidence, and anxiety were the three main types that have been investigated by many researchers. Listening ability is the third factor. People should comprehend what is uttered to them in order to have a successful dialogue.

Topical knowledge is the fourth factor. Topical knowledge is the speakers' knowledge of related topical information. It enables people to apply language with respect to the world in which they live. The fifth factor is related to the feedback during speaking activities. The fear of speaking English is pertinent to some personality constructs like anxiety, inhibition, and risk taking. Speaking a language sometimes results in anxiety. Sometimes, extreme anxiety may lead to despondence and a sense of failure in learners (Bashir, Azeem, \& Dogar 2011). According to Woodrow (2006), anxiety has a negative effect on the oral performance of English speakers. Adults are very careful to making errors in whatever they tell. In their opinion, errors show a kind of unawareness which can hinder them to speak English in front of other people. Inhibition is a feeling of worry that stops people from telling or performing what they want (Cambridge A. L. Dictionary, 2008). All human beings make a series of defenses to protect the ego. Due to the fact that committing mistakes is a natural process of learning a language, it certainly causes potential threats to one's ego. These threats disappoint the learners to talk English and prefer to be silent rather than being criticized in front of a large number of people (Brown, 2000). Risk-taking is pertinent to inhibition and self-respect.

\section{METHOD}

The primary data required for the research was collected using questionnaire. The research instrument in this study was a close and openended questionnaire. A questionnaire was designed to explore the language needs of villa Besar staff, whereas the professionals were interviewed. The findings highlighted the communicative activities and language skills required by the villa Besar staff. Questionnaire was divided into three parts. Part 1 for the general information of the respondents. This section contained the respondents' information about sex, age, educational background, duration of work in their position, the necessity of English in their job area, as well as the opinions about using English language skills. Part II asking information about problems of English in communication, and the last one in Part III was the need of English competency improvement both general and also English for villa industry. A fivepoint Likert scale was used for the respondents to rate.

\begin{tabular}{|l|l|}
\hline $\begin{array}{l}\text { Rates of } \\
\text { opinion }\end{array}$ & $\begin{array}{l}\text { Interpretation of the } \\
\text { scale }\end{array}$ \\
\hline 5 & Very high \\
\hline 4 & High \\
\hline 3 & Moderate \\
\hline 2 & Low \\
\hline 1 & Very low \\
\hline
\end{tabular}

\begin{tabular}{|l|l|}
\hline Mean & Level of problem \\
\hline $4.21-5.00$ & Very high \\
\hline $3.41-4.20$ & High \\
\hline $2.61-3.40$ & moderate \\
\hline $1.81-2.60$ & Low \\
\hline $1.00-1.80$ & Very low \\
\hline
\end{tabular}


Apart from the above mentioned tools the relevant secondary data for the research was collected from journals, books \& internet.

Population is the total member of research subject (Arikunto, 2010:173). The population of this study was the entire of villa Besar staff. Sample is a part of population which will be investigated (Arikunto, 2010:174). The sample of this study was all of the villa Besar Staff at Jl. Bumbak. The sample was taken by using total sampling where the entire population who had a particular set of characteristics had been examined. The sample in this study was 42 participants who were working in the Front Office Department, Housekeeping Department, Food and Beverage Department, Security and Engineering. This study used observation method or participant observation. Participant observation was conducted in order to listen and observe the conversation between villa Besar staff and foreigner customers. This kind of participant observation is required because it gives that data needed (Arikunto, 2010: 237).

\section{DATA ANALYSIS AND FINDINGS}

Verbal communication skills is an important pre-requisite for a career in the tourism industry like villa. Based on the questionnaires distributed to the entire of villa Besar staffs could be obtained data as follows:

1. General Information of the Respondents

Table 1. Gender

\begin{tabular}{lcc}
\hline Gender & Frequency & Percentage \\
\hline Male & 18 & 42.8 \\
\hline Female & 24 & 57.2 \\
\hline Total & 42 & 100.0 \\
\hline
\end{tabular}

Table 1 showed that most of the respondents $(57.2 \%)$ were female and $42.8 \%$ were male.
Table 2. Age

\begin{tabular}{|c|c|c|}
\hline Age & Frequency & Percentage \\
\hline $20-25$ & 6 & 14.3 \\
\hline $26-30$ & 10 & 23.8 \\
\hline $31-35$ & 16 & 38.1 \\
\hline $36-40$ & 4 & 9.5 \\
\hline $\begin{array}{l}\text { More than } \\
40\end{array}$ & 6 & 14.3 \\
\hline Total & 42 & 100.0 \\
\hline \multicolumn{3}{|c|}{$\begin{array}{l}\text { Table } 2 \text { showed that most of } \\
\text { them }(38.1 \%) \text { were between } 31-35 \\
\text { years old. There were } 23.8 \% \text { of them } \\
\text { who were between } 26-30 \text { years old, } \\
\text { and } 14.3 \% \text { of them were between } 20- \\
25 \text { years old and more than } 40 \text { years } \\
\text { old. } 9.5 \% \text { of them were between } 36- \\
40 \text { years old. }\end{array}$} \\
\hline
\end{tabular}

Table 3. Level of Education

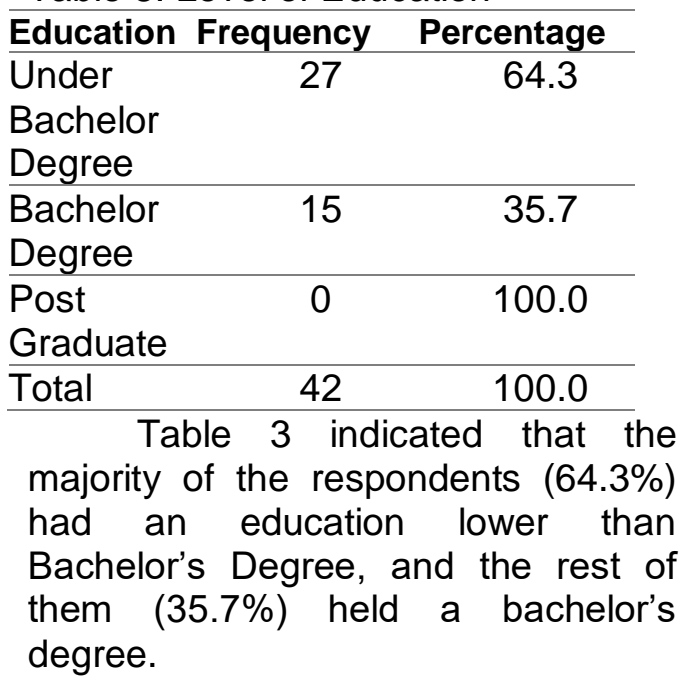

Table 4. Duration of respondent work in their position (Front Office Department, Housekeeping Department, Food and Beverage Department, Security and Engineering)

\begin{tabular}{lcc}
$\begin{array}{l}\text { Duration } \\
\text { (period) } \\
\text { Less than }\end{array}$ & Frequency & Percentage \\
$\begin{array}{l}\text { a year } \\
1-5\end{array}$ & 2 & 4.8 \\
\hline $6-10$ & 14 & 33.3 \\
\hline $11-15$ & 4 & 38.1 \\
\hline $\begin{array}{l}\text { More than } \\
15\end{array}$ & 6 & 9.5 \\
\hline
\end{tabular}


Table 4 showed that $38.1 \%$ of them had worked between 6-10 years. $33.3 \%$ of them had worked between $1-5$ years. $14.3 \%$ of them had worked more than 15 years. $9.5 \%$ of them had worked between 11-15 years. $4.8 \%$ of them had worked less than a year.
Table 5. The necessity of English at work

\begin{tabular}{lcc}
\hline Necessary & Frequency & Percentage \\
\hline Yes & 42 & 100.0 \\
\hline No & 0 & 0 \\
\hline Total & 42 & 100.0 \\
\hline \multicolumn{3}{c}{ From table 5, all of the } \\
respondents $(100 \%)$ needed using \\
English language skill in their job. They \\
all unanimously agreed that English \\
language communication is very \\
important in a career in hospitality.
\end{tabular}

Problem on Using English in Verbal Communication

Table 6. Problem on using English in verbal communication

\begin{tabular}{|c|c|c|c|}
\hline No & Verbal Communication Skill & Mean & $\begin{array}{l}\text { Level of } \\
\text { Problems }\end{array}$ \\
\hline 1 & Welcoming and greeting & 4.01 & High \\
\hline 2 & Inquiring about customer's need and decisions & 3.23 & Moderate \\
\hline 3 & Making polite request & 2.89 & Moderate \\
\hline 4 & $\begin{array}{l}\text { Providing and explaining information about room } \\
\text { details and facilities, menu, and all topic related } \\
\text { to their work }\end{array}$ & 3.10 & Moderate \\
\hline 5 & Offering assistance & 3.48 & High \\
\hline 6 & Giving customers directions & 2.61 & Moderate \\
\hline 7 & Refusing politely & 2.79 & Moderate \\
\hline 8 & $\begin{array}{l}\text { Suggesting travel information( restaurant, } \\
\text { temple, tradition, transportation) }\end{array}$ & 3.00 & Moderate \\
\hline 9 & Conducting conversation by phone & 3.15 & Moderate \\
\hline 10 & Apologizing when mistake occur & 2.87 & Moderate \\
\hline 11 & Explaining the reason for mistake & 3.50 & High \\
\hline 12 & Negotiating for mutual understanding & 3.42 & High \\
\hline 13 & Clarifying questions or confirming messages & 3.70 & High \\
\hline 14 & $\begin{array}{c}\text { Pronouncing English consonant and vowel } \\
\text { sounds }\end{array}$ & 2.63 & Moderate \\
\hline 15 & Speaking with appropriate word stress & 2.61 & Moderate \\
\hline 16 & $\begin{array}{l}\text { Speaking politely according to grammatical rules } \\
\text { and social etiquette }\end{array}$ & 2.70 & Moderate \\
\hline 17 & Knowing vocabulary related to tourism industry & 3.70 & High \\
\hline 18 & Knowing vocabulary related to transportation & 3.58 & High \\
\hline 19 & Knowing vocabulary related to food & 3.42 & High \\
\hline 20 & Knowing vocabulary related to accommodation & 3.49 & High \\
\hline 21 & $\begin{array}{c}\text { Knowing vocabulary related to festivals and } \\
\text { holidays }\end{array}$ & 3.51 & High \\
\hline 22 & Knowing vocabulary related to giving directions & 3.20 & Moderate \\
\hline
\end{tabular}


Based on table 6 , it was obtained that the most problematic activities in verbal communication conducted by Villa Besar staffs were speaking with appropriate word stress and giving customers directions (mean score 2.61), pronouncing English consonant and vowel sounds (mean score 2.63), speaking politely according to grammatical rules and social etiquette (mean score 2.70), refusing politely (mean score 2.79), apologizing when mistake occur (mean score 2.87), and also making polite request (mean score 2.89). This case might occur because the staffs had different background knowledge and the staff did not familiar with the accent of the customers.

The least problematic activities in verbal communication which were perceived by villa Besar staff including suggesting travel information ( restaurant, temple, tradition, transportation) with mean score 3.00 , providing and explaining information about room details and facilities, menu, and all topic related to their work (mean score 3.10), conducting conversation by phone (mean score 3.15), knowing vocabulary related to giving directions (mean score 3.20), and also inquiring about customer's need and decisions (mean score 3.23).

Several skills perceived least significant by villa Besar staff were negotiating for mutual understanding and knowing vocabulary related to food (mean score 3.42), offering assistance (mean score 3.48), knowing vocabulary related to accommodation (mean score 3.49), explaining the reason for mistake (mean score 3.50), knowing vocabulary related to festivals and holidays (mean score 3.51), explaining the reason for mistake (mean score 3.58), clarifying questions or confirming messages and also knowing vocabulary related to tourism industry (mean score 3.70). The easiest speaking skill produced by villa Besar staffs were welcoming and greeting (mean score 4.01).

Factors that Affect Villa Besar Staffs' Verbal Communication Performance, Based on the questionnaire given to Villa Besar staff, it could be obtained some factors which influence their verbal communication performance including performance condition. This case occurred when all of the staff jobs need to communicate with foreign customer like offering food, handling check in/out, telling about accommodation and so on. Besides, this condition was supported by their motivation and self-confident to get good in touch with the foreign customers. They believed with their ability to share information and always exploit the chance they got to communicate with the customers whether to gie information related to their jobs or practice their speaking skills. But on the other hand, they felt anxiety and ashamed to make some error in speaking and the lack of their vocabulary affect their verbal communication performance.

Organizational Support for English Improvement, According to questionnaire distributed to all of Villa Besar staff, more English course whether general English or English for Specific Purposes for tourism should be provided in order to improve the ability of the staff and could give better service to the customers.

\section{CONCLUSION}

Based on the research finding and analysis of questionnaire distributed to all of Villa Besar staffs, it could be concluded that most of the respondents were female with the age mostly between 31-35 years old, but they came from lower education level with 
frequently had experience or working 610 years. All of them highly considered that English is necessary in their job.

Some problems occurred in verbal communication starting from the most problematic activity until the easiest skills in speaking. Some factors affect their verbal communication performance including performance condition, motivation, self-confident, felt anxiety and ashamed.

Although difficulties with verbal communication can't be completely avoided, it is possible to increase chances of communicating successfully like considering the message before speaking and also speak clearly and enunciate the words and be conscious nonverbal aspects such as eye contact, posture and facial expressions.

\section{BIBLIOGRAPHY}

(2008). Cambridge

Advanced Learner's Dictionary, 3rd Ed. Cambridge: Cambridge University Press.

Arikunto, S. (2010). Prosedur Penelitian: Suatu Pendekatan Praktik (Edisi Revisi). Jakarta: Rineka Cipta.

Bashir, M., Azeem, M., \& Dogar, A. H. (2011). Factor Effecting Students' English Speaking Skills. British Journal of Arts and Social Sciences, 2(1), 34-50.

Brown, H. Douglas. 2000. Principles of Language Learning and Teaching. Fourth Edition. New York: Longman.

Efrizal, D. (2012). Improving Students' Speaking through

Communicative Language

Teaching Method at Mts Jaalhaq, Sentot Ali Basa Islamic Boarding School of Bengkulu, Indonesia. International Journal of Humanities and Social Science, 2(20), 127-134.

Eissa, A., Misbah, \& Najat, A. (1988). Problems of Using English as a Medium of Instruction and
Communication at the College of

Science, Kuwait University. Educational Journal, 4(15),47-94.

Hedge, T. (2000). Teaching and Learning in the Language Classroom. Oxford: Oxford University Press.

Hughes, R. (2002). Teaching and Researching Speaking. New York: Pearson Education.

Kostic, B. M. (2011). Importance of English language skills in the tourism sector: A comparative study of students/employees perceptions in Croatia. Alma Tourism, 4(3), 10-23.

Mazouzi, S. (2013). Analysis of Some Factors Affecting Learners' Oral Performance. A Case Study: 3rd Year Pupils of Menaa's Middle Schools. M. A. Dissertation, Department of Foreign Languages, English Division, Faculty of Letters and Languages, Mohamed Khider University of Biskra, People's Democratic Republic of Algeria.

Nation, I. S. P., \& Newton, J. (2009). Teaching ESL/EFL Listening and Speaking. ESL \& Applied Linguistics Professional Series. Routledge Taylor \& Francis Group.

Tanveer, M. (2007). Investigation of the Factors That Cause Language Anxiety for ESL/EFL Learners in Learning Speaking Skills and the Influence It Casts on Communication in the Target Language. Dissertation, University of Glasgow.

Tuan, N. H., \& Mai, T. N. (2015). Factors Affecting Students' Speaking Performance at LE Thanh Hien High School. Asian Journal of Educational Research, 3(2),8-23.

Woodrow, L. (2006). Anxiety and Speaking English as a Second Language. RELC Journal, 37(3), 308-328. 
Xianmei, S. (2012). On Interrelations between Language Teaching and Speech Teaching. Theory and Practice in Language Studies, 2(1), 179-182. 